\title{
Physicochemical properties and antioxidant activities of ginger (Zingiber officinale Roscoe) slices according to temperature and duration of hot water treatment
}

\author{
Ji-Young Choi ${ }^{1}$, Yeong-Min Lee ${ }^{2}$, Jiyoon $\mathrm{Kim}^{3}$, Jungsoo $\mathrm{Kim}^{3}$, Saeul Jeong, \\ Sanghyeok Park ${ }^{3}$, Minhyun $\mathrm{Kim}^{3}$, Kwang-Deog $\mathrm{Moon}^{3 *}$ \\ ${ }^{1}$ Research Group of Consumer Safety, Korea Food Research Institute, Wanju 55365, Korea \\ ${ }^{2}$ Health and Environment Institute of Daegu, Daegu 42183, Korea \\ ${ }^{3}$ School of Food Science and Technology, Kyungpook National University, Daegu 41566, Korea

\section{열수 처리 온도 및 시간에 따른 생강 슬라이스의 이화학적 특성 및 항산화능} \\ 최지영 ${ }^{1} \cdot$ 이영민 $^{2} \cdot$ 김지윤 $^{3} \cdot$ 김정수 $^{3} \cdot$ 정새울 $^{3} \cdot$ 박상혁 $^{3} \cdot$ 김민현 $^{3} \cdot$ 문광덕 $^{3 *}$ \\ ${ }^{1}$ 한국식품연구원, ${ }^{2}$ 대구 보건환경연구원, ${ }^{3}$ 경북대학교 식품공학부 식품생물공학전공
}

\begin{abstract}
This study was conducted to determine the optimal hydrothermal pretreatment conditions for manufacturing processed ginger products. Ginger slices heated at different temperatures $\left(60-100^{\circ} \mathrm{C}\right.$ for $\left.1 \mathrm{~h}\right)$ for varying durations $(1-5 \mathrm{~h}$ at $80^{\circ} \mathrm{C}$ ) were compared in terms of their physiochemical properties, antioxidant activities, and functional compound contents. The $\mathrm{pH}$ and soluble solid content decreased with increasing hydrothermal treatment temperature. Browning occurred at temperatures $>80^{\circ} \mathrm{C}$. The 2,2-diphenyl-1-picrahydrazyl and 2,2'-azino-bis(3-ethylbenzothiazoline-6-sulfonic acid) radical scavenging were highest after heating at $80^{\circ} \mathrm{C}$ for $1 \mathrm{~h}$, and the total phenolic compound content showed a similar trend. As the hydrothermal treatment temperature and duration increased, the 6-gingerol content decreased and the 6-shogaol content generally increased. Based on sensory testing of ginger jeonggwa (with sugar syrup) prepared using hot water-treated ginger slices, the optimal hot water treatments were conducted at 70 and $80^{\circ} \mathrm{C}$ for $1 \mathrm{~h}$, with no significant difference between these temperatures in terms of smell, taste, and texture. Therefore, hydrothermal treatment of ginger at $70-80^{\circ} \mathrm{C}$ for $1 \mathrm{~h}$ was a suitable to improve the functionality and antioxidant ability while maintaining the sensory quality. Therefore, this may be used in the production of processed ginger.
\end{abstract}

Keywords : ginger slice, hydrothermal treatment, 6-shogaol, antioxidant capacities, optimal pretreatment condition

\section{Introduction}

Ginger (Zingiber officinale Roscoe) is a perennial herbaceous plant of the Zingiberaceae native to subtropical and tropical regions, and it is grown in tropical and subtropical regions in China, India, Egypt, and Iraq (Lee et al., 2011). In Korea, ginger is mostly produced in Andong and Yeongju of the North Gyeongsang province and Seosan and Dangjin of the South Chungcheong province (Lee and Kim, 2016). The ginger root and stalk feature a unique spicy taste and aroma

*Corresponding author. E-mail : kdmoon@knu.ac.kr, Phone : +82-53-950-5773, Fax : +82-53-950-6772

Received 19 July 2021; Revised 24 August 2021; Accepted 06 September 2021.

Copyright (c) The Korean Society of Food Preservation.

This is an Open Access article distributed under the terms of the Creative Commons Attribution Non-Commercial License (http://creativecommons.org/licenses/by-nc/4.0) which permits unrestricted non-commercial use, distribution, and reproduction in any medium, provided the original work is properly cited. 
and are distributed as fresh ginger, dried ginger, and ginger oil, which are widely utilized as food, medicine, and cosmetics (Lee et al., 1979; Lee et al., 1996). Further, ginger is not only used as a spice worldwide but has been proven to have pharmacological efficacy, based on which it is utilized as digestive aid, medicine for nausea, abdominal pain, low back pain, and diarrhea, and antibacterial agents (Kim et al., 2001). Past studies have compared the constituents (Chung et al., 1996) and amino acid composition of ginger according to the growing regions (Takahashi et al., 1982), and studies have also investigated the spicy component (Chen et al., 1986) and aromatic component that is closely related to the flavor of ginger (Moon et al., 1997). Ginger has a moisture content of $80-90 \%$, and starch accounts for $40-60 \%$ of the entire solid mass (Kim et al., 1991; Shin et al., 1994). The major ingredients of ginger include carbohydrates, ketones, alcohols, and volatile aromatic components, such as zingiberene and $\gamma$-cadinene. Ginger consists of $0.1-0.3 \%$ of oil, and the main ingredients of this oil, the 6-gingerol and 6-shogaol homologues, give ginger its characteristic potent spice, with their content markedly higher than that of other trace ingredients. For this reason, 6-gingerol and 6-shogaol are frequently used as quality indices during storage and distribution of ginger, and they have attracted much attention as potential ingredients of functional foods owing to their antioxidant and anti-inflammatory properties (Connell et al., 1969; Connell et al., 1970). Particularly, 6-gingerol has an antioxidant activity of equivalent to $95 \%$ of that of ascorbic acid (Lee et al., 2006), and as it stabilizes $\beta$-carotene (Lee et al., 1985), many studies have investigated its antioxidant (Chang et al., 1994), anti-cancer (Surh et al., 2002), and anti-bacterial (Ippoushi et al., 2003) effects. With its pharmaceutical effects documented, ginger, along with various herbs, is utilized in developing health supplements and crude drugs.

Ginger is generally harvested in October and November and stored and distributed throughout the year. However, ginger has poor storability, as it is susceptible to chilling injury at a temperature of $10^{\circ} \mathrm{C}$ or lower and is susceptible to germination (Enmaya et al., 1981), mold growth, surface drying, and softening at a temperature of $18^{\circ} \mathrm{C}$ or higher (Jo et al., 1996). In Korea, 58,947 tons of ginger was produced in 2016, with the production growing at an annual rate of about $15.4 \%$, and the ginger market size is about 535.9 billion KRW, also growing at an annual rate of $14.2 \%$ (Chungcheongnam-do Agricultural Research and Extension Services, 2017), indicating growing demands. To address the challenges of ginger storage and increase the diversity of ginger consumer products, past studies have investigated the optimal quality characteristics of sweet-rice muffins containing ginger powder (Lee et al., 2011), rheological characteristics of pound cake containing ginger powder (Chung et al., 2012), quality characteristics of ginger juice-added muffins (Han et al., 2012), quality characteristics of apple jams made with ginger (Lee et al., 2014), quality characteristics of all-purpose flour containing ginger powder (Lee et al., 2021), and cookies containing ginger powder (Kwon et al., 2021). In terms of processed ginger, candied ginger accounts for nearly half of all processed ginger products (KAMIS). Jeonggwa (candied snacks) is a traditionally Korean snack prepared by lightly boiling plant roots, stalks, or fruits to soften the flesh and slowly braising it in sugar or honey (Kim, 1999). Ginger has a potent spicy flavor, so eliminating the spicy flavor during the candying process is more important for ginger than other types of jeonggwa. Ginger is generally treated with hot water to remove its pungent flavor, and during this process, its active ingredients are lost, and it may be browned or discolored.

While several studies have explored measures to enhance the storability of ginger and ginger-containing processed food products, studies on hydrothermal treatment, an essential step in producing candied ginger, are lacking. Thus, this study applied hydrothermal treatment to ginger slices at varying temperatures and durations and analyzed the changes in physicochemical, functional, and sensory characteristics to identify the optimal conditions for hydrothermal treatment that do not impair the quality of processed ginger products. The results of this study would be useful as basic data for producing processed products using ginger.

\section{Materials and method}

\section{Materials and hydrothermal treatment}

For this experiment, ginger produced in Seosan, South Chungcheong Province that are similar in color and size and has no blemishes. Ginger washed in running water was cut into 0.4-cm slices using a vegetable cutter (RG-100, Hallde, 
Kista, Sweden). The ginger slices were placed in a water bath (WMB-311, Daihan Scientific, Seoul, Korea) with water at a $1: 10(\mathrm{w} / \mathrm{v})$ ratio and heated at $60^{\circ} \mathrm{C}, 70^{\circ} \mathrm{C}, 80^{\circ} \mathrm{C}$, $90^{\circ} \mathrm{C}$, and $100^{\circ} \mathrm{C}$ for $1 \mathrm{~h}$. For the evaluation of suitability for food processing by temperature of hydrothermal treatment, the temperature was fixed to $80^{\circ} \mathrm{C}$, which was the temperature at which the best results were obtained in the functional ingredient experiment, and to establish the optimal duration of hydrothermal treatment, ginger and water were heated in a water bath (WMB-311, Daihan Scientific, Seoul, Korea) at a 1:10 (w/v) ratio for $1 \mathrm{~h}, 2 \mathrm{~h}$, $3 \mathrm{~h}, 4 \mathrm{~h}$, and $5 \mathrm{~h}$. The ginger slices were taken out immediately after the hydrothermal treatment and drained for an analysis of the characteristics.

\section{Physicochemical quality characteristics}

For the $\mathrm{pH}$ and soluble solid content analysis, the hydrothermal-treated ginger slices were immersed in distilled water of a volume fourfold greater than the sample and ground using a homogenizer (AM-9, Nihonseiki Kashima Co., Ltd., Tokyo, Japan). The $\mathrm{pH}$ of the prepared sample was measured using a $\mathrm{pH}$ meter ( $\mathrm{pH} 510$ Benchtop Meter, Oakton Instruments, IL, USA), and the dilution factor was not reflected in the $\mathrm{pH}$ value. Soluble solid content was measured using a refractometer (Master- $\alpha$, ATAGO Co., Tokyo, Japan) and presented as ${ }^{\circ}$ Brix, and the dilution factor was not reflected in the measurement. Color was analyzed by arbitrarily choosing 10 samples from each treatment group and making three repeated chrominance measurements at the center of a cross-section of the ginger slices. The average value was used, and a colorimeter (CR-400, Konica Minolta Co., Osaka, Japan) calibrated with a standard white plate $\left(\mathrm{L}^{*}=97.79, \mathrm{a}^{*}=-0.38, \mathrm{~b}^{*}=2.05\right)$ was used. The color difference between pre- and post-treatment samples was calculated using the following equation:

$$
\Delta \mathrm{E}=\sqrt{\left(\Delta \mathrm{L}^{*}\right)^{2}+\left(\Delta \mathrm{a}^{*}\right)^{2}+\left(\Delta \mathrm{b}^{*}\right)^{2}}
$$

\section{Antioxidant activity}

A modified version of the Blois method (Blois et al., 1958) was used for the 1,1-diphenyl-2-picrylhydral (DPPH) radical assay. The sample was prepared through ultrasoundassisted extraction of the ginger slices in $80 \%$ ethanol (40 $\mathrm{kHz}$, Daihan Scientific Co., Ltd., Seoul, Korea) for $30 \mathrm{~min}$ at room temperature $\left(20 \pm 5^{\circ} \mathrm{C}\right)$ and four rounds of filtration with Whatman filters. $0.4 \mathrm{mM}$ DPPH (Sigma- Aldrich, MO, USA) solution was adjusted with ethanol to achieve an absorbance of 0.95-0.99 and mixed with the sample solution at 4:1 ratio. After incubating the mixture for $10 \mathrm{~min}$, absorbance was read at $517 \mathrm{~nm}$ using a UV-Visible spectrophotometer (Evolution 201, Thermo Fisher Scientific, MA, USA), and the DPPH radical scavenging activity was computed using the following equation:

$$
\begin{aligned}
& \text { DPPH radical scavenging activity }(\%)= \\
& \frac{\text { Blank absorbance - Sample absorbance }}{\text { Blank absorbance }}
\end{aligned}
$$

ABTS radical scavenging activity was measured with reference to the method proposed by Re et al. (1999). 7.4 $\mathrm{mM}$ ABTS was mixed with $2.45 \mathrm{mM}$ potassium persulphate (Sigma-Aldrich, MO, USA) at 1:1 ratio and incubated for $14 \mathrm{~h}$ in dark to form cation radicals $\left(\right.$ ABTS $^{+}{ }^{+}$). The solution was then diluted such that the absorbance value is below 1.00 at $734 \mathrm{~nm}$. $20 \mu \mathrm{L}$ of sample solution was added to 980 $\mu \mathrm{L}$ of the diluted $\mathrm{ABTS}^{+}{ }^{+}$solution and incubated for $10 \mathrm{~min}$ before reading absorbance. The result was presented as Trolox equivalent $(\mu \mathrm{M})$ using Trolox (6-hydroxy-2,5,7,8tetramethylchroman-2-carboxylic acid; Sigma-Aldrich, MO, USA) as the standard substance.

\section{Total phenol content}

Total phenol content (TPC) was quantified based on the Folin-Ciocalteu method (Benvenuti et al., 2004). The sample was prepared through ultrasound-assisted extraction of the ginger slices in $80 \%$ ethanol (40 kHz, Daihan Scientific Co., Ltd., Seoul, Korea) for $30 \mathrm{~min}$ at room temperature $(20 \pm$ $5^{\circ} \mathrm{C}$ ) and four rounds of filtration with Whatman filters. 1 $\mathrm{mL}$ of the sample solution was mixed with $1 \mathrm{~mL}$ of FolinCiocalteu reagent (Junsei Chemical Co. Ltd., Tokyo, Japan), incubated for $15 \mathrm{~min}$, mixed with $1 \mathrm{~mL}$ of $10 \% \mathrm{Na}_{2} \mathrm{CO}_{3} 1$ mL (Duksan Pure Chemicals Co., Ansan, South Korea) and incubated for another $60 \mathrm{~min}$ in dark. Absorbance was measured at $700 \mathrm{~nm}$ using a UV-Visible spectrophotometer (Evolution 201, Thermo Fisher Scientific, MA, USA), and the TPC was presented as tannic acid equivalent (TAE) $\mathrm{mg} / \mathrm{L}$ using tannic acid (Chameleon Chemicals, Osaka, Japan) as the standard substance. 


\section{6-Gingerol, 6-shogaol contents}

To analyze the 6-gingerol, 6-shogaol contents of hydrothermal-treated ginger slices, the sample was prepared through ultrasound-assisted extraction in $80 \%$ methanol (40 kHz, Daihan Scientific Co., Ltd., Seoul, Korea) for $30 \mathrm{~min}$ and filtration through a $0.45-\mu \mathrm{m}$ membrane filter. The methods proposed by Gorecki et al. (1997) and He et al. (1998) that enable simultaneous analysis of 6-gingerol and 6-shogaol were applied to perform high performance liquid chromatography (HPLC) (Model Prominence, Shimadzu, Kyoto, Japan). The YMC-Peak Pro C18 (4.6×250 nm, $5 \mu \mathrm{m}$, $120 \AA$ ) was used as the column, with the temperature set at $30^{\circ} \mathrm{C}$. A gradient system with water and acetronitrile was used for the mobile phase. The flow rate was set at $1.0 \mathrm{~mL} / \mathrm{min}$, and the volume of sample injection was set at $20 \mu \mathrm{L}$.

\section{Sensory evaluation}

Sensory evaluation was performed by 15 adequately trained graduate students of the Gyeongbuk National University. The samples for the sensory evaluation were prepared by mixing the ginger slices treated at each experimental condition with sugar at a 2:1 ratio and braising it for about $40 \mathrm{~min}$ at $80^{\circ} \mathrm{C}$. The evaluation consisted of color, appearance, odor, taste, ginger taste, hardness, chewiness, and overall preference using a five-point scale.
The students were instructed to mark 1 for low preference due to off-taste and off-flavor and to mark 5 for high preference. The sensory evaluation was exempted for review by the Institutional Review Board at Gyeongbuk National University (Application number: 2021-0096) and proceeded safely.

\section{Statistical processing}

All experimental measurements were taken three times, and the results were presented as mean and standard deviation (mean $\pm \mathrm{SD}$ ). The results were analyzed with ANOVA and Duncan's multiple range test $(\mathrm{p}<0.05)$ using the SAS program (SAS 9.4, SAS Institute, Inc., Cary, NC, USA).

\section{Results and discussion}

\section{$\mathrm{pH}$ and soluble solid content}

Table 1 shows the $\mathrm{pH}$ and soluble solid contents of ginger slices by heating conditions. The $\mathrm{pH}$ of ginger slices tended to decrease with increasing temperature of hydrothermal treatment and with increasing duration of hydrothermal treatment. This is consistent with previous findings that $\mathrm{pH}$ decreased with increasing temperature of thermal treatment of bellflower (Platycodon grandifloras) (Song et al., 2018). Kim et al. (2014) reported that hydrothermal-treated carrots

Table 1. Physicochemical properties of heat-treated ginger slices under various temperature and time conditions

\begin{tabular}{|c|c|c|c|c|c|c|}
\hline Samples & & $\mathrm{pH}$ & $\begin{array}{l}\text { Soluble solid } \\
\left.\text { contents ( }{ }^{\circ} \text { Brix }\right)\end{array}$ & $\mathrm{L}^{*}$ & $a^{*}$ & $b^{*}$ \\
\hline \multirow{6}{*}{$\begin{array}{c}\text { Temperature }^{1)} \\
\left({ }^{\circ} \mathrm{C}\right)\end{array}$} & Control & $6.26 \pm 0.09^{\mathrm{cd} 2)}$ & $0.93 \pm 0.06^{\mathrm{g}}$ & $82.97 \pm 3.02^{\mathrm{de}}$ & $-4.61 \pm 1.05^{\mathrm{ef}}$ & $48.97 \pm 3.96^{\mathrm{e}}$ \\
\hline & 60 & $6.33 \pm 0.03^{\mathrm{d}}$ & $0.77 \pm 0.06^{\mathrm{f}}$ & $85.36 \pm 1.60^{\mathrm{f}}$ & $-7.18 \pm 0.83^{b c}$ & $47.80 \pm 3.76^{\mathrm{de}}$ \\
\hline & 70 & $6.26 \pm 0.02^{\mathrm{cd}}$ & $0.63 \pm 0.06^{\mathrm{e}}$ & $83.67 \pm 2.94^{\mathrm{ef}}$ & $-7.63 \pm 0.45^{\mathrm{ab}}$ & $46.30 \pm 4.19^{\mathrm{cd}}$ \\
\hline & 80 & $6.21 \pm 0.01^{\mathrm{bc}}$ & $0.43 \pm 0.06^{\mathrm{d}}$ & $77.50 \pm 5.26^{\mathrm{c}}$ & $-7.99 \pm 0.78^{\mathrm{a}}$ & $44.76 \pm 4.67^{\mathrm{bc}}$ \\
\hline & 90 & $6.15 \pm 0.07^{\mathrm{b}}$ & $0.27 \pm 0.06^{\mathrm{c}}$ & $73.54 \pm 4.03^{\mathrm{b}}$ & $-6.69 \pm 1.02^{c}$ & $44.70 \pm 6.25^{\mathrm{bc}}$ \\
\hline & 100 & $6.07 \pm 0.03^{\mathrm{a}}$ & $0.17 \pm 0.06^{\mathrm{ab}}$ & $69.83 \pm 2.67^{\mathrm{a}}$ & $-4.81 \pm 1.36^{\mathrm{de}}$ & $43.90 \pm 4.55^{\mathrm{bc}}$ \\
\hline \multirow{5}{*}{ Time (h) } & 1 & $6.21 \pm 0.01^{\mathrm{bc}}$ & $0.43 \pm 0.06^{\mathrm{d}}$ & $77.50 \pm 5.26^{\mathrm{c}}$ & $-7.99 \pm 0.78^{\mathrm{a}}$ & $44.76 \pm 4.67^{\mathrm{bc}}$ \\
\hline & 2 & $6.20 \pm 0.02^{\mathrm{bc}}$ & $0.23 \pm 0.06^{\mathrm{bc}}$ & $81.21 \pm 3.91^{\mathrm{d}}$ & $-6.70 \pm 1.15^{\mathrm{c}}$ & $44.70 \pm 3.70^{\mathrm{bc}}$ \\
\hline & 3 & $6.32 \pm 0.01^{\mathrm{d}}$ & $0.20 \pm 0.00^{\mathrm{bc}}$ & $78.19 \pm 3.83^{\mathrm{c}}$ & $-6.62 \pm 1.13^{c}$ & $42.30 \pm 4.47^{\mathrm{ab}}$ \\
\hline & 4 & $6.27 \pm 0.01^{\mathrm{cd}}$ & $0.10 \pm 0.00^{\mathrm{a}}$ & $77.55 \pm 5.45^{\mathrm{c}}$ & $-5.30 \pm 1.44^{\mathrm{d}}$ & $42.95 \pm 5.58^{\mathrm{ab}}$ \\
\hline & 5 & $6.32 \pm 0.03^{\mathrm{d}}$ & $0.10 \pm 0.00^{\mathrm{a}}$ & $76.28 \pm 5.67^{\mathrm{c}}$ & $-4.11 \pm 1.47^{\mathrm{f}}$ & $40.85 \pm 6.93^{\mathrm{a}}$ \\
\hline
\end{tabular}

1) Temperature treatment, $1 \mathrm{~h}$; time treatment, $80^{\circ} \mathrm{C}$.

${ }^{2)}$ Mean \pm SD $(n=3)$ with different letters are significantly different $(p<0.05)$. 
had the lowest organic acid content compared to carrots with other types of pretreatment (steaming, stir frying). This was speculated to be due to the possibility that organic acids were volatilized by heat or were extracted into the hot cooking water (Lee and Jung, 2012). Further, this result was similar to the report by Lee et al. (2005), where $\mathrm{pH}$ increased over time after hydrothermal immersion treatment as organic acids were extracted. In general, $\mathrm{pH}$ change is closely linked to organic acid content and is used as a marker of biochemical change, and it has been reported that prolonged thermal treatment at high temperatures facilitates the biochemical changes of ginger (Chung et al., 2009). Soluble solid content of ginger slices significantly decreased with increasing temperature and duration of hydrothermal treatment. This is in line with the results of Lee et al. (2015) that total sugar content of burdock declines with steaming due to the extraction of water-soluble sugar ingredients and that of Yoon et al. (2005) that the soluble solid content of heattreated ginseng decreases with increasing temperature and duration of heating.

\section{Color and discoloration}

Table 1 shows the color (CIE L*a*b*) results of heated ginger. The $L^{*}$ value significantly decreased with increasing temperature of hydrothermal treatment but did not differ according to the duration of hydrothermal treatment. The $\mathrm{a}^{*}$ value decreased below that of non-treated samples with weaker heat treatment, resulting in a greenish color. However, the value increased to a level comparable to the non-treated samples with increasing temperature and duration of hydrothermal treatment. In other words, weak hydrothermal treatment can actually cause ginger to develop a greenish color. The $b^{*}$ value significantly decreased with increasing temperature and duration of hydrothermal treatment. Curcumine, the yellow pigment found in ginger, is insoluble in cold water but dissolves well in warm water and is vulnerable to heat (Kim, 2007). Thus, the extraction of curcumine into the hot water seems to have resulted in a lower $b^{*}$ value of ginger slices (Jung et al., 2004; Jung et al., 2012). Fig. 1 shows the $\Delta \mathrm{E}$ and browning index (BI) of the non-treated sample and treated samples. The $\Delta \mathrm{E}$ value significantly increased from 6.59 to 15.15 with increasing treatment temperature but did not markedly change according to the duration of treatment. Considering that there were no
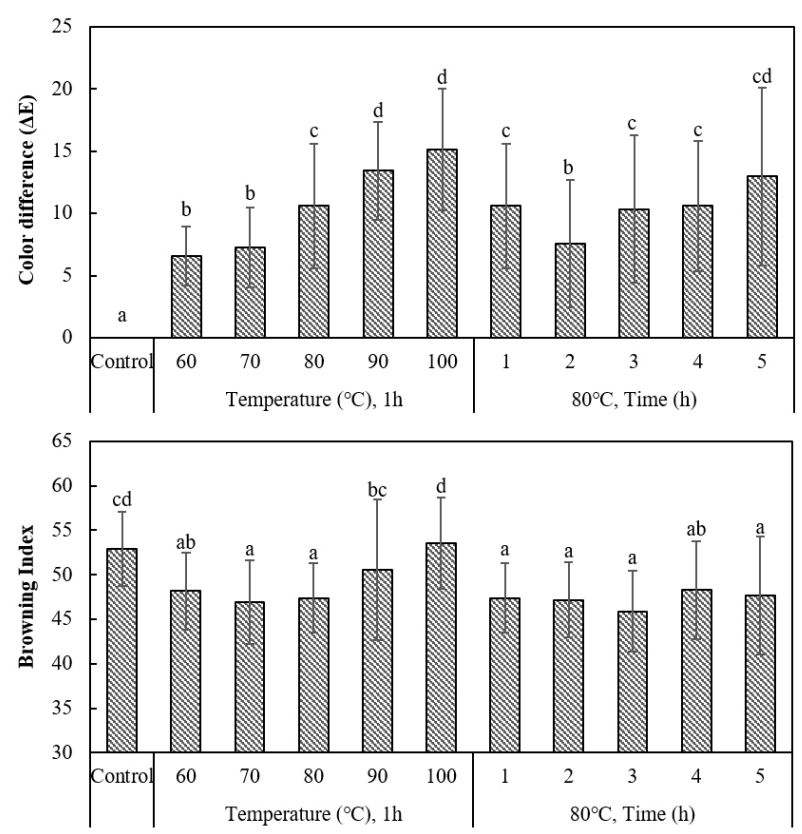

Fig. 1. Browning index and color difference of heat-treated ginger slices under various temperature and time conditions.

Mean $(n=30)$ with different letters are significantly different $(\mathrm{p}<0.05)$.

significant changes when the temperature was fixed at $80^{\circ} \mathrm{C}$ and durations of treatment were extended, the surface color of ginger seems to be more heavily influenced by the temperature of treatment rather than the duration of treatment. Regarding the BI, the BI was lower than the non-treated group when treated with $60-80^{\circ} \mathrm{C}$ for $1 \mathrm{~h}$, but the index increased to a similar level to that of the non-treated group when the temperature was increased to $90^{\circ} \mathrm{C}$ or higher. When the temperature was fixed to $80^{\circ} \mathrm{C}$ and the duration was varied, the range of BI was significantly lower (45.90-48.27) than the non-treated group, with no significant differences among the treated groups. These results were similar to that of Kang and Hyun (2007), where curcumine content did not significantly differ according to the duration of water extraction of turmeric (30-180 min) but did significantly differ according to the temperature of extraction. As shown in Table 1, the $\mathrm{L}^{*}$ value is more sensitive to the temperature of treatment, rather than the duration of treatment, where it markedly decreases at higher temperatures, thereby also affecting the BI. Jo et al. (1996) reported that browning of ginger generally is due to the Maillard reaction primarily involving fructose and asparagine and nonenzymatic browning involving the oxidation of 
ascorbic acid, and that the brightness value decreased. Chun et al. (1986) showed that when glucose+glysine solution and fructose+glysine solution were heated at varying temperatures, the Maillard reaction was dramatically facilitated from a temperature of about $90^{\circ} \mathrm{C}$.

In conclusion, treatment with hot water at $60-80^{\circ} \mathrm{C}$ facilitated the extraction of curcumine into the hot water, resulting in a brighter color or lower $\mathrm{BI}$ compared to the non-treated samples. However, hydrothermal treatment at a temperature of $90^{\circ} \mathrm{C}$ or higher triggered the Maillard reaction and caused browning.

\section{Antioxidant activity and TPC}

Table 2 shows the DPPH and ABTS radical scavenging activities and TPC by heating condition. DPPH radical scavenging activity of ginger slices increased with increasing temperature of hydrothermal treatment and peaked at $80^{\circ} \mathrm{C}$, after which it declined. This is similar to the results of Ross et al. (2011), where radical scavenging activity increased proportionally to heating temperature and duration and then decreased from a certain point. The decreasing DPPH radical scavenging activity with increasing duration of heat treatment is speculated to be due to the extraction or alteration of the active ingredients of ginger slices as a result of extended heat treatment. Further, based on the degree of change, DPPH radical scavenging activity seems to be more heavily influenced by the temperature of treatment than duration of treatment. The ABTS radical scavenging activity of ginger slices increased with increasing temperature of heat treatment and peaked at $80^{\circ} \mathrm{C}(596.91 \mu \mathrm{M})$, after which it declined. The scavenging activity decreased with increasing duration of heating, similar to the results of DPPH radical scavenging activity. The higher ABTS radical scavenging activity compared to the DPPH radical scavenging activity is reported to be due to the difference in the radicaleliminating mechanisms and substrate binding (Re et al., 1999). The TPC of ginger slices was the highest at $80^{\circ} \mathrm{C}$ and tended to decrease with increasing duration of hydrothermal treatment. This is similar to the results of Kim et al. (2008), where TPC of fruits and vegetables increased with increasing temperature of heat treatment and decreased from a certain point. Yoon et al. (2005) reported that phenolic compounds were more easily extracted from ginseng with higher heating temperature and duration and that insoluble phenolic compounds were isolated from high-molecular compounds and degraded to free phenolic compounds, consistent with the findings of this study. Furthermore, DPPH and ABTS radical scavenging activity and TPC were higher at a temperature of $80^{\circ} \mathrm{C}$ or higher early in the heating (1st h) compared to the control (raw ginger), presumably due to an elevation of melanoidins, a brown product of the Maillard reaction (Do et al., 1989). However, as prolonged heat

Table 2. Antioxidant activities and total phenol content of ginger slices at different boiling temperature and time

\begin{tabular}{|c|c|c|c|c|}
\hline Samples & & DPPH (\%) & ABTS $(\mu \mathrm{M})$ & TPC (mg/L) \\
\hline \multirow{6}{*}{ Temperature $^{1)}\left({ }^{\circ} \mathrm{C}\right)$} & Control & $27.22 \pm 2.88^{\mathrm{b} 2)}$ & $225.63 \pm 20.56^{\mathrm{a}}$ & $30.68 \pm 3.49^{\mathrm{ab}}$ \\
\hline & 60 & $20.90 \pm 1.27^{\mathrm{a}}$ & $135.63 \pm 8.04^{\mathrm{a}}$ & $18.50 \pm 0.19^{\mathrm{a}}$ \\
\hline & 70 & $34.12 \pm 6.17^{\mathrm{c}}$ & $221.56 \pm 35.33^{\mathrm{a}}$ & $21.08 \pm 0.50^{\mathrm{bc}}$ \\
\hline & 80 & $57.73 \pm 2.76^{\mathrm{g}}$ & $596.91 \pm 36.67^{c}$ & $56.05 \pm 0.88^{\text {bcd }}$ \\
\hline & 90 & $55.96 \pm 0.87^{\mathrm{g}}$ & $484.52 \pm 21.27^{\mathrm{c}}$ & $45.49 \pm 2.11^{\mathrm{cd}}$ \\
\hline & 100 & $42.09 \pm 2.30^{\mathrm{d}}$ & $333.41 \pm 43.81^{\mathrm{b}}$ & $50.03 \pm 4.87^{\mathrm{d}}$ \\
\hline \multirow{5}{*}{ Time (h) } & 1 & $57.73 \pm 2.76^{\mathrm{g}}$ & $596.91 \pm 36.67^{\mathrm{c}}$ & $56.05 \pm 0.88^{\text {bcd }}$ \\
\hline & 2 & $54.23 \pm 0.93^{\mathrm{fg}}$ & $487.96 \pm 1.74^{\mathrm{bc}}$ & $53.15 \pm 1.81^{\mathrm{ab}}$ \\
\hline & 3 & $54.24 \pm 0.79^{\mathrm{fg}}$ & $492.30 \pm 17.23^{\mathrm{c}}$ & $49.97 \pm 0.55^{\text {bcd }}$ \\
\hline & 4 & $45.64 \pm 3.51^{\text {de }}$ & $485.15 \pm 40.26^{\mathrm{c}}$ & $39.67 \pm 1.14^{\mathrm{bc}}$ \\
\hline & 5 & $48.98 \pm 4.65^{\mathrm{ef}}$ & $453.04 \pm 19.51^{\mathrm{c}}$ & $40.48 \pm 1.40^{\mathrm{e}}$ \\
\hline
\end{tabular}

${ }^{1)}$ Temperature treatment, $1 \mathrm{~h}$; time treatment, $80^{\circ} \mathrm{C}$.

${ }^{2)}$ Mean \pm SD $(n=3)$ with different letters are significantly different $(\mathrm{p}<0.05)$. 
treatment may actually break down phenol components (Kim et al., 2014), and antioxidant substances are released into the hot water, the TPC may be lower after long heat treatment compared to the earlier values. In conclusion, the antioxidant capacity and TPC of ginger slices were more substantially influenced by temperature changes than the duration of treatment, with the values peaking after $1 \mathrm{~h}$ of treatment at $80^{\circ} \mathrm{C}$.

\section{6-Gingerol, 6-shogaol contents}

Table 3 shows the 6-gingerol and 6-shogaol contents, the major functional ingredients, of ginger following hydrothermal treatment. 6-gingerol content was the highest in the $70^{\circ} \mathrm{C}$ group $(215.55 \mathrm{mg} / \mathrm{L})$ and began to decrease from $80^{\circ} \mathrm{C}$ with the lowest content in the $100^{\circ} \mathrm{C}$ group $(95.77 \mathrm{mg} / \mathrm{L})$. This is similar to the results of Bhattarai et al. (2001) that 6-gingerol content decreases at high temperatures because it is converted to 6-shogaol at high temperatures. 6-Gingerol prevents phospholipid oxidation by the iron chloride ascorbate ( $\mathrm{FeCl}_{3}$-ascorbate) system and inhibits xanthine oxidase, an enzyme that contributes to the formation of reactive oxygen species such as superoxide anions (Lee et al., 2006). 6-Shogaol is produced by dehydration of gingerol and has been reported to have biochemical effects such as

Table 3. 6-Gingierol and 6-shogaol content of ginger slices at different boiling temperature and time

$(\mathrm{mg} / \mathrm{L})$

\begin{tabular}{|c|c|c|c|}
\hline \multicolumn{2}{|c|}{ Samples } & \multirow{2}{*}{$\frac{\text { 6-Gingerol }}{188.81 \pm 6.00^{\mathrm{f} 2)}}$} & \multirow{2}{*}{$\begin{array}{c}\text { 6-Shogaol } \\
6.28 \pm 0.34^{\mathrm{a}}\end{array}$} \\
\hline \multirow{6}{*}{$\begin{array}{c}\text { Temperature } \\
\left({ }^{\circ} \mathrm{C}\right)\end{array}$} & Control & & \\
\hline & 60 & $205.45 \pm 12.16^{\mathrm{g}}$ & $6.27 \pm 0.36^{\mathrm{a}}$ \\
\hline & 70 & $215.55 \pm 8.28^{\mathrm{g}}$ & $7.51 \pm 0.19^{b}$ \\
\hline & 80 & $165.59 \pm 9.12^{\mathrm{e}}$ & $7.23 \pm 0.08^{\mathrm{b}}$ \\
\hline & 90 & $145.84 \pm 0.92^{\mathrm{d}}$ & $9.26 \pm 0.35^{\mathrm{c}}$ \\
\hline & 100 & $95.77 \pm 4.75^{\mathrm{c}}$ & $15.87 \pm 0.52^{\mathrm{f}}$ \\
\hline \multirow{5}{*}{ Time (h) } & 1 & $165.59 \pm 9.12^{\mathrm{e}}$ & $7.23 \pm 0.08^{\mathrm{b}}$ \\
\hline & 2 & $94.47 \pm 8.49^{c}$ & $11.65 \pm 0.79^{d}$ \\
\hline & 3 & $78.40 \pm 4.12^{\mathrm{b}}$ & $14.51 \pm 0.47^{\mathrm{e}}$ \\
\hline & 4 & $65.69 \pm 4.05^{\mathrm{a}}$ & $16.62 \pm 0.76^{\mathrm{f}}$ \\
\hline & 5 & $59.48 \pm 2.95^{\mathrm{a}}$ & $16.71 \pm 0.77^{\mathrm{f}}$ \\
\hline
\end{tabular}

${ }^{1)}$ Temperature treatment, $1 \mathrm{~h}$; time treatment, $80^{\circ} \mathrm{C}$.

${ }^{2)}$ Mean \pm SD ( $\left.n=3\right)$ with different letters are significantly different $(\mathrm{p}<0.05)$. antibacterial and antioxidant effects. The 6-shogaol has been reported to have superior anti-inflammatory, antioxidant, and anti-cancer effects compared to 6-gingerol (Chang et al., 1994). 6-Shogaol content remained unchanged at low temperatures but increased at higher temperatures, peaking at $100^{\circ} \mathrm{C}(15.87 \mathrm{mg} / \mathrm{L})$. It also significantly increased with increasing duration of heating, with the highest content $(16.71 \mathrm{mg} / \mathrm{L})$ in the $5 \mathrm{~h}$ group. These results are similar to those reported by Ok et al. (2012), where 6-shogaol content of ginger increased with increasing drying and extraction temperatures. Further, Cheng et al. (2011) also reported that 6-shogaol content increases with decreasing 6-gingerol content and is inversely proportional to the degree of exposure to heat during processing. Therefore, the temperature or duration of hydrothermal treatment should be raised to increase the content of 6-shogaol, a functional ingredient, in ginger.

\section{Sensory evaluation}

Table 4 shows the results of sensory evaluation of candied ginger prepared by braising hydrothermal-treated ginger slices with sugar at a 2:1 ratio. The appearance preference score for the control group was 3.5, and the sample with the highest preference score for appearance was the ginger hydrothermal treated at $60^{\circ} \mathrm{C}$ for $1 \mathrm{~h}$. Similarly, the preference for color was also the highest for the $60^{\circ} \mathrm{C}$ treatment group, followed by control group, $70^{\circ} \mathrm{C}$ group, $80^{\circ} \mathrm{C}$ group, $100^{\circ} \mathrm{C}$ group, and $90^{\circ} \mathrm{C}$ group. Ginger slices treated at higher temperatures and for longer durations would have had the Maillard reaction involving sugars and amino acids that causes browning (Kim et al., 2018), which would have contributed to less preferred appearance and color. The preferences for odor, taste, ginger taste, hardness, chewiness, and overall preference did not significantly differ according to the conditions of hydrothermal treatment. In terms of the duration of heating, the $2 \mathrm{~h}$ group was rated to have the most preferred appearance and color, and the preference score tended to decrease with increasing duration of treatment beyond this point. On the other hand, there were no significant trends observed for odor, taste, and chewiness. The sample treated at $80^{\circ} \mathrm{C}$ for $5 \mathrm{~h}$ was given a markedly lower score for ginger taste and overall preference. The browning caused by longer duration and higher temperature of heating led to significantly different color, and particularly, browning caused by long pre-treatment influenced the 
Table 4. Sensory evaluation of ginger jeonggwa at different temperature and time at hot water treatment

$(\mathrm{mg} / \mathrm{L})$

\begin{tabular}{|c|c|c|c|c|c|c|c|c|c|}
\hline Sample & & Appearance & Color & Odor & Taste & Ginger taste & Chewiness & Hardness & $\begin{array}{c}\text { Overall } \\
\text { preference }\end{array}$ \\
\hline \multirow{6}{*}{$\begin{array}{c}\text { Temperature } \\
\text { (C) }\end{array}$} & Control & $\begin{array}{c}3.50 \\
\pm 0.85^{\mathrm{bc} 2)}\end{array}$ & $\begin{array}{l}3.80 \\
\pm 1.03^{\mathrm{cd}}\end{array}$ & $\begin{array}{c}3.80 \\
\pm 1.55^{\mathrm{a}}\end{array}$ & $\begin{array}{c}3.70 \\
\pm 1.06^{\mathrm{a}}\end{array}$ & $\begin{array}{c}3.80 \\
\pm 1.14^{\mathrm{b}}\end{array}$ & $\begin{aligned} & 2.90 \\
\pm & 1.10^{\mathrm{abc}}\end{aligned}$ & $\begin{array}{c}3.90 \\
\pm 1.10^{\mathrm{c}}\end{array}$ & $\begin{array}{c}3.80 \\
\pm 1.14^{\mathrm{b}}\end{array}$ \\
\hline & 60 & $\begin{array}{c}3.80 \\
\pm 1.40^{\mathrm{c}}\end{array}$ & $\begin{array}{c}4.10 \\
\pm 1.29^{\mathrm{d}}\end{array}$ & $\begin{array}{c}3.70 \\
\pm 1.06^{\mathrm{a}}\end{array}$ & $\begin{array}{c}2.70 \\
\pm 1.16^{\mathrm{a}}\end{array}$ & $\begin{array}{c}4.40 \\
\pm 0.84^{\mathrm{b}}\end{array}$ & $\begin{array}{c}3.30 \\
\pm 1.06^{\mathrm{abc}}\end{array}$ & $\begin{aligned} & 3.40 \\
\pm & 1.07^{\mathrm{abc}}\end{aligned}$ & $\begin{array}{c}3.10 \\
\pm 1.45^{\text {ab }}\end{array}$ \\
\hline & 70 & $\begin{array}{c}3.50 \\
\pm 1.27^{\mathrm{bc}}\end{array}$ & $\begin{aligned} & 3.70 \\
\pm & 1.06^{\mathrm{cd}}\end{aligned}$ & $\begin{array}{c}3.60 \\
\pm 1.43^{\mathrm{a}}\end{array}$ & $\begin{array}{c}3.20 \\
\pm 1.03^{\mathrm{a}}\end{array}$ & $\begin{array}{l}3.60 \\
\pm 1.07^{\mathrm{b}}\end{array}$ & $\begin{array}{c}2.50 \\
\pm 0.97^{\mathrm{a}}\end{array}$ & $\begin{array}{l}3.80 \\
\pm 1.23^{\mathrm{bc}}\end{array}$ & $\begin{array}{l}3.80 \\
\pm 1.48^{\mathrm{b}}\end{array}$ \\
\hline & 80 & $\begin{array}{c}3.00 \\
\pm 0.67^{\mathrm{abc}}\end{array}$ & $\begin{array}{c}3.10 \\
\pm 0.74^{\mathrm{bc}}\end{array}$ & $\begin{array}{c}3.20 \\
\pm 1.62^{\mathrm{a}}\end{array}$ & $\begin{array}{c}3.20 \\
\pm 1.48^{\mathrm{a}}\end{array}$ & $\begin{array}{c}3.80 \\
\pm 0.92^{\mathrm{b}}\end{array}$ & $\begin{aligned} & 3.50 \\
\pm & 1.08^{\mathrm{bc}}\end{aligned}$ & $\begin{aligned} & 3.10 \\
\pm & 0.88^{\text {abc }}\end{aligned}$ & $\begin{array}{c}3.70 \\
\pm 0.82^{\mathrm{b}}\end{array}$ \\
\hline & 90 & $\begin{array}{c}2.60 \\
\pm 1.17^{\mathrm{ab}}\end{array}$ & $\begin{array}{c}2.70 \\
\pm 1.16^{\mathrm{b}}\end{array}$ & $\begin{array}{c}3.10 \\
\pm 1.52^{\mathrm{a}}\end{array}$ & $\begin{array}{c}3.40 \\
\pm 1.35^{\mathrm{a}}\end{array}$ & $\begin{array}{c}3.70 \\
\pm 0.67^{\mathrm{b}}\end{array}$ & $\begin{array}{c}2.80 \\
\pm 1.23^{\mathrm{abc}}\end{array}$ & $\begin{array}{c}3.50 \\
\pm 1.35^{\mathrm{bc}}\end{array}$ & $\begin{array}{c}3.30 \\
\pm 1.06^{\mathrm{ab}}\end{array}$ \\
\hline & 100 & $\begin{array}{c}3.10 \\
\pm 0.99^{\mathrm{abc}}\end{array}$ & $\begin{array}{c}3.00 \\
\pm 1.15^{\mathrm{bc}}\end{array}$ & $\begin{array}{c}3.40 \\
\pm 1.26^{\mathrm{a}}\end{array}$ & $\begin{array}{c}3.60 \\
\pm 1.35^{\mathrm{a}}\end{array}$ & $\begin{array}{c}3.70 \\
\pm 1.16^{\mathrm{b}}\end{array}$ & $\begin{array}{c}3.10 \\
\pm 1.10^{\mathrm{abc}}\end{array}$ & $\begin{array}{c}3.40 \\
\pm 0.52^{\mathrm{abc}}\end{array}$ & $\begin{array}{c}3.30 \\
\pm 0.67^{\mathrm{ab}}\end{array}$ \\
\hline \multirow{5}{*}{ Time (h) } & 1 & $\begin{array}{c}3.00 \\
\pm 0.67^{\mathrm{abc}}\end{array}$ & $\begin{array}{c}3.10 \\
\pm 0.74^{\mathrm{bc}}\end{array}$ & $\begin{array}{c}3.20 \\
\pm 1.62^{\mathrm{a}}\end{array}$ & $\begin{array}{c}3.20 \\
\pm 1.48^{\mathrm{a}}\end{array}$ & $\begin{array}{c}3.80 \\
\pm 0.92^{\mathrm{b}}\end{array}$ & $\begin{array}{c}3.50 \\
\pm 1.08^{\mathrm{bc}}\end{array}$ & $\begin{array}{c}3.10 \\
\pm 0.88^{\text {abc }}\end{array}$ & $\begin{array}{c}3.70 \\
\pm 0.82^{\mathrm{b}}\end{array}$ \\
\hline & 2 & $\begin{array}{c}3.40 \\
\pm 0.52^{\mathrm{abc}}\end{array}$ & $\begin{array}{c}3.70 \\
\pm 0.67^{\text {cd }}\end{array}$ & $\begin{array}{c}3.20 \\
\pm 0.92^{\mathrm{a}}\end{array}$ & $\begin{array}{c}2.70 \\
\pm 0.48^{\mathrm{a}}\end{array}$ & $\begin{array}{c}3.70 \\
\pm 0.67^{\mathrm{b}}\end{array}$ & $\begin{array}{c}3.60 \\
\pm 0.52^{\mathrm{c}}\end{array}$ & $\begin{array}{c}2.90 \\
\pm 0.74^{\mathrm{ab}}\end{array}$ & $\begin{array}{c}3.70 \\
\pm 0.48^{\mathrm{b}}\end{array}$ \\
\hline & 3 & $\begin{array}{c}2.80 \\
\pm 0.42^{\mathrm{ab}}\end{array}$ & $\begin{array}{c}2.30 \\
\pm 0.48^{\mathrm{b}}\end{array}$ & $\begin{array}{c}4.20 \\
\pm 0.63^{\mathrm{a}}\end{array}$ & $\begin{array}{c}2.90 \\
\pm 0.32^{\mathrm{a}}\end{array}$ & $\begin{array}{c}3.50 \\
\pm 0.71^{\mathrm{b}}\end{array}$ & $\begin{array}{c}2.50 \\
\pm 0.53^{\mathrm{a}}\end{array}$ & $\begin{array}{c}2.50 \\
\pm 0.85^{\mathrm{a}}\end{array}$ & $\begin{array}{c}3.40 \\
\pm 0.52^{\mathrm{b}}\end{array}$ \\
\hline & 4 & $\begin{array}{c}2.80 \\
\pm 0.42^{\mathrm{ab}}\end{array}$ & $\begin{array}{c}2.40 \\
\pm 0.52^{\mathrm{b}}\end{array}$ & $\begin{array}{c}3.50 \\
\pm 0.53^{\mathrm{a}}\end{array}$ & $\begin{array}{c}2.60 \\
\pm 0.52^{\mathrm{a}}\end{array}$ & $\begin{array}{c}3.70 \\
\pm 0.48^{\mathrm{b}}\end{array}$ & $\begin{array}{c}2.60 \\
\pm 0.70^{\mathrm{ab}}\end{array}$ & $\begin{array}{c}3.80 \\
\pm 0.42^{\mathrm{bc}}\end{array}$ & $\begin{array}{c}2.90 \\
\pm 0.74^{\mathrm{ab}}\end{array}$ \\
\hline & 5 & $\begin{array}{c}2.50 \\
\pm 0.53^{\mathrm{a}}\end{array}$ & $\begin{array}{c}1.40 \\
\pm 0.52^{\mathrm{a}}\end{array}$ & $\begin{array}{c}3.20 \\
\pm 0.42^{\mathrm{a}}\end{array}$ & $\begin{array}{c}3.40 \\
\pm 0.52^{\mathrm{a}}\end{array}$ & $\begin{array}{c}2.60 \\
\pm 0.84^{\mathrm{a}}\end{array}$ & $\begin{array}{c}3.00 \\
\pm 0.47^{\mathrm{abc}}\end{array}$ & $\begin{aligned} & 3.60 \\
\pm & 0.52^{\mathrm{bc}}\end{aligned}$ & $\begin{array}{c}2.40 \\
\pm 0.52^{\mathrm{a}}\end{array}$ \\
\hline
\end{tabular}

${ }^{1)}$ Temperature treatment, $1 \mathrm{~h}$; time treatment, $80^{\circ} \mathrm{C}$.

${ }^{2)}$ Mean \pm SD ( $\left.n=3\right)$ with different letters are significantly different $(\mathrm{p}<0.05)$.

overall preference for candied ginger. However, the heating conditions did not have noticeable effects on the properties, taste, and odor overall. Thus, heating ginger at lower than $80^{\circ} \mathrm{C}$ for less than $3 \mathrm{~h}$ would not alter the sensory qualities of candied ginger.

\section{요 약}

본 연구에서는 열수처리 시 생강편의 이화학적 변화와 기 능성 성분의 변화를 평가하여 생강 가공품 생산의 기초적 자 료를 제공하고자 하였다. 열수처리된 생강편의 $\mathrm{pH}$ 는 열수처 리 온도가 증가할수록 감소하였고 시간에 따른 경향성은 나 타나지 않았다. 생강편의 가용성 고형분 함량은 열처리 온도 와 시간이 증가함에 따라 유의적으로 감소하는 경향을 나타 내었다. 생강편의 $\mathrm{L}^{*}$ value와 $\mathrm{b}^{*}$ value는 열처리 온도와 시간 이 증가함에 따라 유의적으로 감소하는 경향을 나타내었고 $a^{*}$ value는 증가하였다. 갈변도를 산출해 본 결과에서는 1 시
간 동안 열수처리 시 $80^{\circ} \mathrm{C}$ 이상부터 갈변이 발생했다. 생강편 의 $\mathrm{DPPH}, \mathrm{ABTS}$ 라디칼 소거능은 $80^{\circ} \mathrm{C}$ 에서 1 시간 가열한 처리구가 가장 높게 나타내었으며, 그 이상으로 열처리 시간 길어지거나, 온도가 높아질수록 감소하는 경향을 보였다. 생 강편의 총 페놀성 화합물 함량 또한 항산화능 실험 결과와 유사한 경향을 나타내었다. 열수 처리 온도와 시간이 증가할 수록 6-gingerol 함량은 감소하였으며 6-shogaol 함량은 증가 하는 경향을 나타내었다. 다양한 조건으로 열수 처리된 생강 편으로 생강정과를 제조하여 관능검사를 수행한 결과, 종합 적 기호도는 $70^{\circ} \mathrm{C}$ 와 $80^{\circ} \mathrm{C}$ 에서 1 시간 동안 열수 처리된 것이 가장 높았으며, 냄새나 맛, 식감 부분에 있어서는 기호도에 유의미적 차이가 없었다. 이상의 실험 결과로 미루어 보아 생 강은 열수 처리 시간보다 온도에 민감하게 반응하였으며, 생 강을 1 시간 동안 $70-80^{\circ} \mathrm{C}$ 에서 열수 처리하는 것이 관능적 품 질을 유지하면서 기능성과 항산화능을 향상시킬 수 있는 조 건이었다. 이는 가공품으로 제조되기 전 적절한 전처리로 활 용될 수 있을 것으로 사료된다. 


\section{Conflict of interests}

The authors declare no potential conflict of interest.

\section{ORCID}

Ji-Young Choi https://orcid.org/0000-0002-7854-9277 Kwang-Deog Moon

https://orcid.org/0000-0001-5277-3345

\section{References}

Benvenuti S, Pellati F, Melegari M, Bertelli D. Polyphenols, anthocyanins, ascorbic acid, and radical scavenging activity of Rubus, Ribes, and Aronia. J Food Sci, 69, 164-169 (2004)

Bhattarai S, Tran VH, Duke CC. The stability of gingerol and shogaol in aqueous solutions. J Pharm Sci, 90, 1658-1664 (2001)

Blois MS. Antioxidant determination by the use of a stable free radical. Nature, 26, 1198-1204 (1958)

Chang WS, Chang YH, Lu FJ, Chiang HC. Inhibitory effects of phenolics on xanthine. Anticancer Res, 14, 501-506 (1994)

Chen CC, Rosen RT, Ho CT. Chromatagraphic analyses of gingerol compounds in ginger extracted by liquid carvin dioxide. J Chromatog, 360, 163-173 (1986)

Cheng XL, Liu Q, Peng YB, Qi LW, Li P. Steamed ginger (Zingiber officinale): Changed chemical profile and increased anticancer potential. Food Chem, 129, 17851792 (2011)

Chun YH, Kim CK, Kim WJ. Effect of temperature, $\mathrm{pH}$ and sugars on kinetic propertiy of Maillard reaction. Korean J Food Sci Technol, 18, 55-60 (1986)

Chung HS, Lee HJ, Seong JH, Moon KD. Effects of heat pretreatment on the quality under storage of fresh ginger rhizomes. J Korean Food Preserv, 16, 623-628 (2009)

Chung TY, Jeong MC, Lee SE, Kim DC, Kim OW. Morphological characteristics of ginger depending on habitat. Korean J Food Sci Technol, 28, 834-840 (1996)

Chung YK, Lee JJ, Lee HJ. Rheological properties of pound cake with ginger powder. J Korean Food Preserv, 19, 361-367 (2012)

Lee JW. Studies on Cultivation Method for Stable
Prouduction of Ginger. Final Report of RDA, PJ011317 (2017)

Connell DW, Sutherland MD. A re-examination of gingerol, shogaol, and zingerone the pungent principle of ginger (Zingiber officinale Roscoe). Aust J Chem, 22, 10331043 (1969)

Connell DW. The chemistry of the essential oil and oleoresin of ginger (Zingiber officinale Roscoe). Flavour Ind, 1, 677-693 (1970)

Do JH, Kim KH, Jang JG, Yang JW, Lee KS. Changes in color intensity and components during browning reaction of white ginseng water extract. Korean J Food Sci Technol, 21, 480-485 (1989)

Enmaya H. Dictionary of Food Science. Dou Dan Publishing Co, Tokyo, Japan, p 300 (1981)

Gorecki P, Segiet-Kujawa E, Gaedcke P, Kurt H, Feistel B. Isolation of 6-gingerol from Zingiber officinale Roscoe by chromatographic methods. Herba Polonica Tom, XLIII, 43, 202-207 (1997)

Han EJ. Quality characteristics of muffins containing ginger juice. J Korean Culi Res, 18, 256-266 (2012)

He X, Bernart M, Lian L, Lin L. High-performance liquid chromatography electrospray mass spectrometric analysis of pungent constituents of ginger. J Chromatography A, 796, 327-334 (1998)

Ippoushi K, Azuma K, Ito H, Horie H, Higashio H. [6]Gingerol inhibits nitric oxide synthesis in activated J774.1 mouse macrophages and prevents peroxynitriteinduced oxidation and nitration reactions. J Life Sci, 73, 3427-3437 (2003)

Jo KS, Kim JG, Shin HS. Major components affecting nonenzymatic browning in ginger (Zingiber Officinale Roscoe) paste during storage. Korean J Food Sci Technol, 28, 433-439 (1996)

Jung SH, Chang KS, Ko KH. Physiological effects of curcumin extracted by supercritical fluid from turmeric (Curcuma longa L.). Korean J Food Sci Technol, 36, 317-320 (2004)

Jung YS, Park SJ, Park JH, Jhee KH, Lee IS, Yang SA. Effects of ethanol extracts from Zingiber officinale Rosc., Curcuma longa L., and Curcuma aromatica Salisb. on acetylcholinesterase and antioxidant activities as well as GABA content. J Korean Soc Food Sci Nutr, 41, 1395-1401 (2012) 
Kang SK, Hyun KH. Optimization of curcumin extraction and removal of bitter substance from Curcuma longa $\mathrm{L}$. Korean J Food Preserv, 14, $722-726$ (2007)

Kim HH, Lee SJ, Chung YH, Kim SH, Sung NJ. Physicochemical properties and antioxidant activities from hot-air and freeze dried aged black ginger (Zingiber officinale). J Life Sci, 28, 153-161 (2018)

Kim HY, Woo KS, Hwang IG, Lee YR, Jeong HS. Effects of heat treatments on the antioxidant activities of fruits and vegetables. Korean J Food Sci Technol, 40, 166-170 (2008)

Kim JS, Koh MS, Kim MK, Hong JS. Volatile flavor components of Korean ginger (Zingiber officinale Roscoe). Korean J Food Sci Technol, 23, 141-149 (1991)

Kim KI, Hwang IG, Yoo SM, Min SG, Choi MJ. Effects of various pretreatment methods on physicochemical and nutritional properties of carrot. J Korean Soc Food Sci Nutr, 43, 1881-1888 (2014)

Kim MY, Chun SS. Effects of onions on the quality characteristics of strawberry jam. J Korean Food Cookery Sci, 17, 316-322 (2001)

Kim SB, Do JR, Lee YW, Gu YS, Kim CN, Park YH. Nitrite-scavenging effects of roasted-barley extracts according to processing conditions. Korean J Food Sci Technol, 22, 748-752 (1990)

Kim SJ. Domestic and overseas technology trends in the field of natural dyes. Bulletin of Food Technology, 20, 38-68 (2007)

Kim YT, Lee MS, Kim AJ. Changes in antioxidative activities and general composition of mung beans according to roasting temperature. J East Asian Soc Dietary Life, 24, 217-223 (2014)

Kwon GH, Kim MH, Han YS. Characteristics of cookie quality containing black ginger powder. Culi Sci \& Hos Res, 27, 97-105 (2021)

Lee BS, Ko MS, Kim HJ, Kwak IS, Kim DH, Chung BW. Separation of 6-gingerol from ginger (Zingiber officinale Roscoe) and antioxidative activity. Korean J Biotechnol Bioeng, 21, 484-488 (2006)

Lee CB. Illustrated Flora of Korea. Hyangmoon Publish Co, Seoul, Korea, p 231 (1979)

Lee GY, Son YJ, Jeon YH, Kang HJ, Hwang IK. Changes in the physicochemical properties and sensory characteristics of burdock (Arctium lappa) during repeated steaming and drying procedures. Korean J Food Sci Technol, 47, 336-344 (2015)

Lee HO, Kim BS. Ginger storage management technology. KJACR, 45, 44-51 (2016)

Lee IK, Ahn SY. The antioxidant activity of gingerol. Korean J Food Sci Technol, 17, 55-59 (1985)

Lee JG, Kim KI, Hwang IG, Yoo SM, Min SG, Choi MJ. Effects of various thermal treatments on physicochemical and nutritional properties of shiitake mushrooms. J Korean Soc Food Sci Nutr, 44, 874-881 (2005)

Lee JJ, Jung HO. Changes in physicochemical properties of Spergularia marina Griseb by blanching. Korean J Food Preserv, 19, 866-872 (2012)

Lee JJ, Park JJ, Lee HJ. Rheological properties of all-purpose flour containing ginger powder and the quality characteristics of its product. Korean J Community Living Sci, 32, 57-69 (2021)

Lee SM. Quality characteristics of apple jam added with ginger. Culi Sci \& Hos Res, 20, 79-88 (2014)

Lee SM, Joo NM. Characteristics and optimization of processed sweet rice muffin using ginger powder. J Korean Food Cookery Sci, 27, 31-43 (2011)

Lee YN. Flora of Korea. Kyohaksa, Seoul, Korea, p 1107-1109 (1996)

Moon HI, Lee JH. Volatile aromatic components of ginger rhizome sand Japanese spice bush. Korean J Crop Sci, 42, 7-13 (1997)

Ok S, Jeong WS. Optimization of extraction conditions for the 6-shogaol-rich extract from ginger (Zingiber officinale Roscoe). J Food Sci, 17, 166-171 (2012)

Re R, Pellegrini N, Proteggente A, Pannala A, Yang M, Rice-Evans C. Antioxidant activity applying an improved ABTS radical cation decolorization assay. Free Radical Bio Med, 26, 1231-1237 (1999)

Ross CF, Hoye C JR, Fernandez-Plotka VC. Influence of heating on the polyphenolic content and antioxidant activity of grape seed flour. J Food Sci, 76, C884-C890 (2011)

Shin DH. Survey on consumer concept and acceptability of convenient ginger product. Korea J Diet Culture, 9, 323-327 (1994)

Song MS, Kim YM, Jang GY, Lee YJ, Li M, Oh HA, Lee JS, Jeong HS. Changes in quality characteristics in the normal and etteum Doraji (Platycodon grandiflorum) by 
heat treatment. J Korean Soc Food Sci Nutr, 47, 462467 (2018)

Surh YJ. Anti-tumor promoting potential of selected spice ingredients with antioxidative and anti-inflammatory activities: A short review. Food Chem Toxicology, 40, 1091-1097 (2002)

Takahashi M, Osawak K, Sato T, Ueda J. Components of aminoacids of Zinga officinale Roscoe. Ann Reptohoku Coll Pharm, 29, 75-88 (1982)
Yoo BH, Jang HS, Lee SB. Chromaticity analysis of curcumin extracted from curcuma and turmneric: Optimization using response surface methodology. Appl Chem Eng, 30, 421-428 (2019)

Yoon SR, Lee MH, Park JH, Lee IS, Kwon JH, Lee GD. Changes in physicochemical compounds with heating treatment of ginseng. J Korean Soc Food Sci Nutr, 34, 1572-1578 (2005) 